\title{
Why this time is different: The North Korea Crisis and New Zealand's interests.
}

Author/s: Reuben Steff

To cite this article: Steff, R. (2020). Why This Time is Different: The North Korea Crisis and

New Zealand's Interests. National Security Journal. doi:10.36878/nsj20200201.01

To link to this article: https://doi.org/10.36878/nsj20200201.01

View CrossRef data: https://search.crossref.org/?q=10.36878\%2Fnsj20200201.01 


\title{
WHY THIS TIME IS DIFFERENT: THE NORTH KOREA CRISIS AND NEW ZEALAND'S INTERESTS
}

\author{
Reuben Steff ${ }^{1}$
}

\begin{abstract}
North Korea remains the ultimate international outlier: an isolated totalitarian state seeking to acquire a credible nuclear weapons program. As such, a simmering crisis between the North and the US has been playing out since the end of the Cold War. Yet, while past attempts at diplomacy have failed, change is afoot as the Trump administration seeks to shift US-North Korean relations onto a new footing. While skepticism is warranted, this article explains that new personalities and a shift in the structure of power in and around the Korean peninsula provide grounds for cautious optimism that long-term rapprochement is feasible. Small states like New Zealand have a stake in a positive outcome, as its interests dictate that it seeks a stable and secure Asia-Pacific. Furthermore, US-North Korean negotiations take place against the backdrop of intensifying US-China great power competition; a situation that complicates the picture and suggests that long-term peace on the peninsula is only possible if diplomacy takes into account all regional actors. With the above in mind, this articles makes a contribution to our understanding of the North Korean issue. It provides a background to the crisis; outlines how personal and structural changes (in terms of the shifting balance of power) suggest that the outcome of diplomatic efforts could be different to failures of the past; considers whether North Korea is an 'irrational' actor; and offers a conceptual (and self-avowedly idealistic) framework - 'strategic liberalism' - to act as a guide for New Zealand as it looks to calibrate its approach to ongoing tensions and diplomacy on the Korean peninsula.
\end{abstract}

Keywords: New Zealand, North Korea, Northeast Asia, Trump Administration, Balance of Power, Nuclear Proliferation, Rapprochement

1 Dr Reuben Steff is a Senior Lecturer, Department of Political Science and Public Policy, Waikato University. Contact reuben.steff@waikato.ac.nz. 


\section{Introduction}

North Korea, officially known as the Democratic People's Republic of Korea (DPRK), remains the ultimate international outlier: an isolated totalitarian state that has resisted efforts to reunify with South Korea - the Republic of Korea (ROK) - and exhibits aggressive behaviour towards the outside world. Of great concern has been the determined efforts by the North to acquire nuclear warheads and ballistic missiles to deliver them - an effort that has accelerated markedly in recent years. ${ }^{1}$ Given that repeated attempts at diplomacy have failed, it is difficult to be confident that the new round of diplomacy will, ultimately, be successful. One constant is that political situations change and assuming the way things are is the way they will always be is a poor basis for analysis in what is an increasingly dynamic international environment. As such, this paper seeks to contribute to our understanding of the changes taking place in and around the Korean peninsula. These changes are both structural and personality-driven. Collectively they are driving, albeit in fits and starts, the DRPK and ROK on one hand, and the DPRK and the US on the other, to de-escalate tensions and attempt to move their relations onto a more positive footing. The stakes involved are high. Failure to break out of the historical impasse risks a new and higher level of tension emerging in Northeast Asia. Additionally, the changing global balance of power between the US and China, and outbreak of great power competition between them, positions North Korea as an issue that could very well test whether Washington and Beijing will be able to cooperate to settle thorny geopolitical issues in the years ahead, or if zero-sum competition will prevail.

New Zealand's interests are in a stable and secure Asia-Pacific, and thus it has voiced its support for recent diplomatic efforts. ${ }^{2}$ Owing to an interconnected and interdependent international system, the consequences of crises and conflicts in distant regions do not stay localised. Rather, they cascade outwards to affect the interests of far-flung states, including New Zealand. Thus, to the extent it can, New Zealand's interests dictate that it should contribute actively towards the success of diplomacy on the Korean peninsula. With the above in mind, this paper seeks to make a contribution to New Zealand policymakers, academics and security practitioners' understanding of the North Korean issue. Additionally, it outlines a conceptual (and self-avowedly idealistic) framework to act as a guide for diplomats and officials as they look to calibrate New Zealand's approach to ongoing tensions and diplomacy over the Korean peninsula. This article adopts a blended theoretical approach afforded by the integrative potential inherent in 'strategic liberalism. While realism is used in parts to explain and examine the North Korean crisis, it must be recognized that material factors and systemic pressures are not the sole determinant of state actions (Waltz, 1979); strategic futures are not pre-determined and liberal tenets are a fulcrum for states to take action to improve their collective security, thus recognising and advancing national interests. The recommendation section of this article advances from this understanding. 
This article makes its contribution through five steps. First, it considers the interrelationship between New Zealand's interests and the simmering crisis on the Korean peninsula. Second, it provides some geographic context, explaining that North Korea is a victim of its location that has made it a 'buffer state' between larger powers. Third, it provides a history of the DPRK's quest to acquire a nuclear deterrent, and touches upon the question of whether North Korea, labelled by some a 'rogue state', is an irrational actor or one responding to structural incentives. Fourth, it examines the recent rounds of diplomacy that began in the wake of Donald Trump's victory in the 2016 US presidential election, and outlines a number of factors that make the context for negotiations different this time. Fifth, a conceptual approach, called 'strategic liberalism, ${ }^{3}$ is proffered as a framework New Zealand could embrace. The paper concludes by asserting that North Korea's nuclear quest is part of a rational response to an unforgiving environment and secondly that seeing diplomacy succeed is in New Zealand's interests. Lastly this article identifies some risks of greater engagement and warns that an inclusive peace, rather than one that excludes key regional players such as China, is essential if a long-term peace is to be secured.

\section{New Zealand's Interests}

In 2001 New Zealand Prime Minister Helen Clark stated that New Zealand was "the most strategically secure country in the world." 4 Whether that was true at the time is debateable, yet it communicated a basic fact: New Zealand is geographically remote and, as a consequence, does not face many of the traditional security concerns that confront other states. However, since Clark's statement, the onward march of globalisation has resulted in an increasingly interdependent and interconnected international system whereby geopolitical crises and events can cascade and wreak havoc throughout the system. As such, whatever security distance affords New Zealand its interests, across a range of levels, are connected to stability in distant regions, including Northeast Asia.

The recent 2018 Strategic Defence Policy Statement identifies North Korea as "a critical disarmament and non-proliferation challenge." 5 Specifically, it's continued nuclear and missile development efforts are viewed as increasing the chances for conflict on the peninsula and for horizontal proliferation (regionally this refers to Japan and South Korea, and beyond that to Iran) to take place. ${ }^{6}$ As such, it states that it is in "New Zealand's interests to support efforts towards de-nuclearisation," with the recent inter-Korean and US-North Korea summits cited as positive steps. ${ }^{7}$ The New Zealand Ministry of Foreign Affair's Strategic Intentions 2018 also welcomed "the shift from extreme tension on the Korean Peninsula" following the summits, while also noting "denuclearisation of North Korea remains a challenging, long-term goal." It continues: "New Zealand will also play its part in helping to resolve situations that are destabilising the Asia-Pacific region," which presumably includes North Korea, and seeks to promote 
nuclear disarmament. ${ }^{8}$ These efforts have been bolstered by the reinstatement of a Cabinet position of Minister for Disarmament and Arms Control (which the previous National government had disestablished in 2011).

New Zealand's security and prosperity would be threatened by conflict on the peninsula or a rapid cascade of nuclear proliferation across the region. ${ }^{9}$ During a conflict that involved New Zealand's friend and allies, New Zealand would be expected to play a role potentially through a military contribution to a US or UN-led coalition effort to disarm the DPRK, and then provide humanitarian and potentially peacekeeping assistance in the aftermath of a devastated Korean peninsula. The safety of New Zealand's citizens in Korea would be immediately placed at risk in a conflict, and global trade damaged. Depending upon how it unfolded, a confrontation on the peninsula even runs the risk of pitting the US and China against one another, with either side expecting other states to support their respective positions. Given New Zealand's close security relationship with Washington and high-level of trade with China, this could place New Zealand in a dilemma over who to support (or whether to try remaining neutral, which would have its own risks). ${ }^{10}$

Furthermore, New Zealand needs to bear in mind the expanding range of North Korea's missiles, such as the Hwasong 14 and 15 that suggest Australia (a nation New Zealand is obligated to assist the defence of in a conflict) could now be in range of DPRK missiles. Eventually, its missiles may even be able to reach New Zealand, while a nuclear detonation elsewhere in the Pacific Ocean could have consequences for fishing and sea life, the climate and New Zealand's economy if ocean-borne travel was affected. ${ }^{11}$ Are these threats hypothetical? It no longer appears so. In 2017, Pyongyang issued threats at Australia for supporting the Trump administration's maximum pressure policy and stated they were considering testing a hydrogen bomb over the Pacific in response to President Trump's threat to "totally destroy" the country. ${ }^{12}$

Additionally, events in Ukraine since late 2013 provide a cautionary tale of how a geographically distant crisis can affect New Zealand interests. In short, after Russia annexed Crimea from Ukraine (in response to an uprising there that deposed pro-Russian President Viktor Yanukovych) and emergence of a Russian-backed rebellion in eastern Ukraine, the European Union and Russia imposed sanctions on one another. This resulted in Russia banning dairy imports from Europe, leading to thousands of tonnes of additional dairy products dumped on the international market that halved milk prices and decreased dairy prices overall that have yet to return (except for butter) to pre-crisis levels. ${ }^{13}$ It also forced former Trade Minister Tim Groser to make a sudden departure from Moscow in August 2014, despite being only 24 hours from signing a Free Trade Agreement (FTA) with Russia, Belarus and Kazakhstan (the FTA was expected to deliver \$27 million to the New Zealand economy annually and to ensure New Zealand would not be treated less favourably than other economies. The FTA remains in limbo). ${ }^{14}$ As such, while Russia's seizure of Crimea and activity in eastern Ukraine 
was at odds with New Zealand's interest of seeing a rules-based international system that rejects territorial conquest sustained, it also damaged New Zealand's economic interests and impeded a once-promising relationship between Wellington and Moscow. It is likely that a conflict on the Korean peninsula - while it would differ to that in Eastern Europe - would have negative global political and economic consequences that, in turn, would threaten New Zealand's economic and political interests.

The status quo of a divided peninsula living under the threat of war cannot be sustained in perpetuity while, in the background, the changing balance of power between the US and China creates an uncertain environment for all stakeholders. Indeed, in many ways, as China's power continues to rise relative to the US, the North Korea issue may very well constitute a test of an emerging US-China centric world order; the true test case as to whether they are able to manage major international issues jointly or whether a zero-sum competition will prevail. In the latter scenario, both sides will attempt to settle issues in ways that benefit them and that come at the expense of the other power. As the February 2010 WikiLeaks cables noted, China would only be comfortable with a reunified Korea if it is part of a benign alliance that is not hostile to Beijing. This implores small states like New Zealand to try encouraging these states to cooperate and work to reduce as many points of international friction as possible. As such, New Zealand, and the region, would benefit by continued dialogue and incremental steps towards DPRK denuclearisation, and indeed eventual Korean reunification. The chapter now turns its attention to North Korea, providing context through a brief consideration of its historical experience as a buffer state before outlining its quest to acquire nuclear weapons.

\section{The Tragedy of a Buffer State}

It is important to recognise that the DPRK's efforts to develop an indigenous nuclear deterrent cannot be divorced from the Korean peninsula's geographic location that make the two Koreas - but especially the north given its isolation and economic weakness - relatively weak 'buffer states' caught between more powerful states. The DPRK is located on the northern portion of the Korean peninsula - a peninsula that juts out from the Asian mainland between the Sea of Japan and the Yellow Sea - and it shares a land-border with China along the Amnok River, Russia along the Tumen River, and with South Korea along the Korean Demilitarized Zone (DMZ).

When a balance of power exists between regional powers, a buffer state acts as a 'space' between them. Sometimes, rival powers agree (formally or informally) that the buffer should not host military forces from either of them, thus creating a measure of stability in the region and between major external actors. Research shows that when the balance of power is upset, buffer states are significantly more likely than other states to be occupied by external powers and, at worst, even extinguished. ${ }^{15}$ In doing this, the conquering state gains the opportunity to project influence beyond the buffer state, 
bringing it into direct confrontation with other external powers. Historically, Korea has often found itself in this position time and time again: in the $13^{\text {th }}$ century Genghis Khan's Mongolia overran the peninsula and attempted to invade Japan; Japan invaded Korea in the $16^{\text {th }}$ century trying to dominate China; and in the $20^{\text {th }}$ century Japan once again invaded and occupied Korea, bringing it into it's so called 'East Asian Co-Prosperity Sphere, ultimately leading to war with the US and its allies.

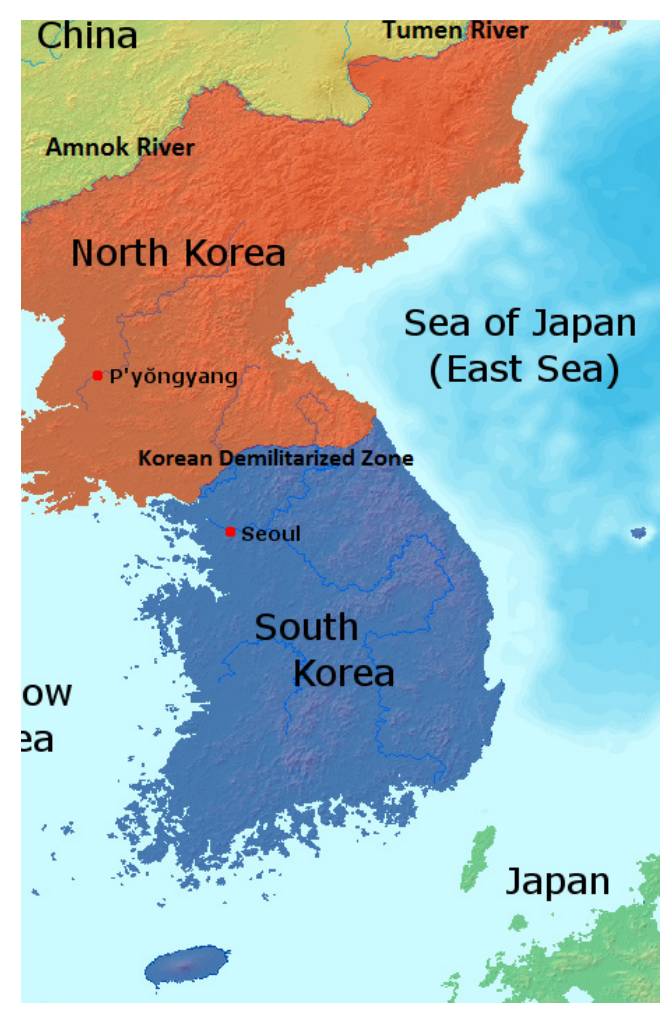

Figure 1: The Korean Peninsula (source: Wikicommons) ${ }^{16}$

The defeat of Japan at the end of World War II did not improve the situation for Korea. In fact, it found itself split between a northern state supported by China and the Soviet Union, and a southern one backed by the United States. From 1950 to 1953, after the North launched an invasion of the South with Soviet backing to reunify Korea under its authority, the peninsula became a prolonged battleground that eventually drew in China and a US-led UN-coalition force. Pyongyang's objective was not achieved, as the peninsula remained divided along the $38^{\text {th }}$ parallel at the conclusion of conflict in $1953 .{ }^{17}$ 
Today, North Korea finds itself squeezed by the US and China: Beijing and Washington view North Korea as a buffer, leaving it vulnerable to decisions either state makes or potentially to future US-Chinese efforts to 'solve' the North Korean situation without Pyongyang's input. In Pyongyang's view, this takes place against a backdrop of worrying regional dynamics, as a number of states, such as China, Taiwan, and South Korea, are all enhancing their military capabilities, while Japan, the old aggressor, is on a path towards military normalisation. ${ }^{18}$ As such, when the DPRK views and interacts with the world, it does so from a position of acute geographic vulnerability.

\section{North Korea's Nuclear Quest}

\section{From Cold War to Obama's 'Strategic Patience'(1945-2014)}

The origins of North Korea's nuclear program go back to 1946, when the Soviet Union began mining uranium in the DPRK ${ }^{19}$ to support the fledging Soviet nuclear program. Soviet-DPRK nuclear cooperation would continue after the Korean War through formal agreements to train Korean scientists and the building of the Yongbyon research reactor $90 \mathrm{~km}$ north of Pyongyang. ${ }^{20}$ Despite their alliance, the DPRK came to question how credible the Soviet Union's extended deterrence guarantee actually was, whereby Moscow committed to defend Communist allies with nuclear weapons if they were threatened. This was informed by the Cuban Missile Crisis of 1962. During the crisis, the Soviet Union was perceived to have backed down in the face of US pressure against Cuba, a distant Communist ally in a situation not unlike the DPRK. ${ }^{21}$ The lesson for Pyongyang was that extended nuclear deterrence guarantees from outside powers were unreliable, leading Pyongyang to begin seeking to acquire uranium from as early as 1963 to develop an indigenous program..$^{22}$

Following the end of the Cold War, prospects for denuclearisation on the peninsula looked good. In December 1991 the DPRK and ROK signed the Joint Declaration on the Denuclearization of the Korean Peninsula. ${ }^{23}$ Following the Declaration, Pyongyang signed the IAEA's safeguards accord in January 1992 and declared its nuclear facilities in May. Despite this progress, a crisis broke out after US intelligence identified unreported sites in mid-1993. Pyongyang denied requests by the IAEA to inspect them and threatened to withdraw from the nuclear Non-Proliferation Treaty (NPT) if the matter was referred to the United Nations Security Council (UNSC). Amidst mounting tensions, US President Clinton drew a red line in November 1993, declaring that "North Korea cannot be allowed to develop a nuclear bomb," ${ }^{24}$ while US Secretary of Defence William Perry stated Washington intended to prevent Pyongyang from developing a nuclear arsenal, even potentially going to war if necessary. ${ }^{25}$ With the crisis in the balance, former US President Jimmy Carter travelled to the DPRK in June 1994, where he secured an $11^{\text {th }}$ hour agreement for the North to suspend its nuclear program in return for energy aid from the United States and light-water reactors. This arrangement was 
secured through the Agreed Framework between the United States of America and the Democratic People's Republic of Korea, signed on 21 October $1994 .{ }^{26}$

Tensions continued to surface throughout the decade, with the US imposing sanctions on the North for continued proliferation activity, and the North launching a three-stage Taepodong-1 missile with a 1,500 to $2,000 \mathrm{~km}$ range in 1998 , revealing that it was continuing to progress its missile programme. ${ }^{27}$ Meanwhile, from 1994 to 2002, the DPRK facilities at Yongbyon remained frozen and five rounds of talks occurred between North Korea and the US on missile proliferation issues. Despite promising diplomatic progress that included an official trip to Pyongyang by US Secretary of State Madeleine Albright in 2000, the arrival of the George W. Bush administration brought this phase of diplomacy to a halt when it initiated a review of US policy on North Korea. Then, following a report by the CIA, the administration declared that Pyongyang had violated its obligations under the NPT, International Atomic Energy Agency (IAEA) and joint South Korea-North Korea Declaration on Denuclearization on the Korean Peninsula. ${ }^{28}$ In January 2002 President Bush included North Korea in a so-called 'axis of evil' alongside Iraq and Iran. According to the Bush administration, these three 'rogue states' were "arming to threaten the peace of the world" and could require pre-emptive military action (what became known as the Bush Doctrine) to forcibly disarm. ${ }^{29}$

On 10 January 2003, North Korea stated that it was withdrawing from the NPT, becoming the first state to pull out of the treaty. ${ }^{30}$ Against the backdrop of the invasion of Iraq in March 2003, diplomacy with North Korea was revived through the Six Party Talks (SPT) that included the US, North Korea, China, South Korea, Japan, and Russia. Yet DPRK nuclear efforts continued. In February 2005, it declared that it had successfully manufactured nuclear weapons "for self-defense to cope with the Bush administration's policy of isolating and crushing the DPRK,"31 and on 9 October 2006 it conducted its first nuclear weapons test. ${ }^{32}$ Meanwhile China, Pyongyang's only 'ally', became increasingly concerned over the North's behaviour, supporting for the first time UNSC Resolution 1695 in July 2006 which condemned North Korea's missile tests, ${ }^{33}$ and supported the October 2006 UNSC Resolution 1718 condeming the nuclear test. ${ }^{34}$

Diplomacy over North Korea remained stillborn for much of the Obama presidency which claimed to be pursuing a strategy of 'strategic patience' vis-à-vis the North. ${ }^{35}$ It was during Obama's second term that the North appeared to be pursuing a full nuclear breakout, seeking to acquire both a credible nuclear weapons capability (a second nuclear test took place in May 2009), as well as weapons delivery systems. These efforts by the DPRK were influenced by the death of Libyan leader Muammar Gaddafi who, despite agreeing to give up the nation's Weapons of Mass Destruction (WMD) and being welcomed back into the ranks of the international community, was killed by US and NATO supported rebels in 2011. North Korea would cite the Libyan episode as justifying why it needed its own nuclear deterrent to prevent US aggression. ${ }^{36}$ 
From 2014 to the end of the Obama administration in January 2017, the North conducted two more nuclear tests (bringing the tally to five) and its testing regime of short, medium and long-range missiles increased markedly. Furthermore, testing became more sophisticated, as it demonstrated mobile platforms, dispersed forces, improved targeting, tested 'salvo' launches to overcome missile defence systems, and pursued nuclear-armed submarines. In other words, testing was becoming more realistic and, while the majority of Pyongyang's missile forces only placed regional targets in range, the test of the Hwasong-14 and Hwasong-15 in 2017, with potential ranges in excess of $10,000 \mathrm{~km}$ and $13,000 \mathrm{~km}$, set alarm bells ringing in Washington, as it suggested the US mainland could soon be threatened by the DPRK's nuclear-armed missiles. ${ }^{37}$

Even China's leader, Xi Jinping, felt compelled after the DPRK staged its third nuclear test in April 2013 to reprimand the North by stating "no one should be allowed to throw a region, and even the whole world, into chaos for selfish gains." ${ }^{38} \mathrm{~A}$ Chinese ban on export items that could facilitate the North's nuclear weapons program followed. ${ }^{39}$ Additional evidence has emerged showing DPRK-Chinese ties have been tense for some time. In a cable dated 28 August 2009 (released by Wikileaks), the North's former leader Kim Jong-il reportedly stated he did not trust China ${ }^{40}$ another cable from April 2009 reported China's Vice Foreign Minister told the US charge d'affaires in Beijing that Pyongyang was acting like a "spoiled child" by conducting missile tests to get US attention, and another from February 2010 reported that South Korea's Vice Foreign Minister told his US counterpart that younger Chinese leaders did not view North Korea as a reliable ally, and "The PRC would be comfortable with a reunified Korea controlled by Seoul and anchored to the United States in a 'benign alliance' - as long as Korea was not hostile towards China." ${ }^{41}$ It is likely that Pyongyang views these statements as additional evidence that its Chinese 'ally' was unreliable, as the Soviet Union was found to be in the 1960s.

\section{Is North Korea an Irrational Actor?}

It is worth pausing here to consider the case that North Korea is an irrational and un-deterrable 'rogue state. ${ }^{42}$ This stems from the idea that the DPRK's leaders may be hell-bent on conquering and forcefully reunifying with the south no matter what. Additionally, they have no democratic polity to answer to and thus, without having to worry about their domestic popularity, could more readily pursue expansionist foreign policies. ${ }^{43}$ Does this characterisation apply to the DPRK? Would it risk suicide to reunify the peninsula under its rule? Thus far, there is little indication that it would. The DPRK has acted aggressively (for example in March 2010 it sunk an ROK naval vessel, the Cheonan, killing 46 seamen, and in November 2010 it bombarded ROK forces on Yeonpyeong Island) and periodically issues bellicose rhetoric but its strategy suggests it 'acts crazy' to strengthen a fairly weak position. ${ }^{44}$ To actually invade the ROK would be to risk regime suicide at the hands of the US military. The superior explanation is 
that the pursuit for a nuclear deterrent is viewed by the DPRK as essential for regime survival rather than territorial conquest. ${ }^{45}$ North Korea's geographic position and experience as a 'buffer state', unreliable allies, confrontation with the US - a nation that Pyongyang has long-viewed as its pre-eminent security threat - drive these efforts. In essence, Pyongyang should not be understood to be an 'irrational' actor but rather one "responding to structural incentives in the international system." ${ }^{46}$ This does not mean that a war on the peninsula cannot occur. After all, rational actors can make gross miscalculations or push a situation to the brink without intending to (as the number of near misses and crises during the Cold War between the Soviet Union and the US attests) indeed, North Korea did precisely this during the crisis of $1994 .{ }^{47}$ But miscalculating is a separate issue to whether acquiring a nuclear deterrent is a rational course to preserve the existing regime in Pyongyang, and to the contention that the North is crazy enough to risk suicide by trying to occupy the ROK - an extremely unlikely decision given the circumstances.

\section{From Nuclear Breakout to Diplomatic Breakout (2017-2020)}

When Donald Trump was elected US president, North Korea was in full nuclear breakout mode, as the number of missile tests increased to their highest annual numbers in 2016 and 2017, and it detonated its sixth, and by far largest, nuclear weapon on 3 September $2017 .{ }^{48}$ Notably, Obama reportedly informed Trump that North Korea was one of the most urgent issues his administration would face. ${ }^{49}$ As such, during a 15-19 March 2017 trip to East Asia, then-Secretary of State Rex Tillerson declared an end to the policy of "strategic patience" as the administration turned to a policy of maximum pressure. ${ }^{50}$ This included a new round of sanctions, deploying increased military assets to the region, and making overt appeals to China to try use its influence to restrain the DPRK's escalating missile and nuclear tests. ${ }^{51}$

The administration's evolving policy had some nuance. For example, President Trump said on 1 May 2017 that he would be "honoured" to meet the North Korean leader, "if it's under... the right circumstances." ${ }^{52}$ In retrospect, Trump's surprising statement may very well have been a canny move that suggested the President was seeking to manage the crisis and, possibly, lay the groundwork for future negotiations. Furthermore, deterrence requires a mix of threats and assurances to work. If a leader only ever issues threats but never assurances, foreign leaders in competition with the US could conclude that there is nothing they can do to appease the US or deter it from conducting regime change in the long run, leading them to take drastic action. This is precisely the outcome an effective deterrence strategy is meant to prevent. ${ }^{53}$

In any event, rhetorical threats continued and tensions mounted. They seemed to reach a head when, in a speech to the UN in September 2017, President Trump vowed to "totally destroy North Korea" if it threatened the US, and he declared that "Rocket Man [Kim Jong-un] is on a suicide mission." ${ }^{34}$ Kim responded that he would deploy the 
"highest level of hard-line countermeasures in history", and called Trump a "mentally deranged US dotard." ${ }^{5}$ And while Trump had suggested he could meet North Korea's leader under the right circumstances, it was still a surprise (even to the South Korean officials who brought it up with him) when, in March 2018, Trump agreed to meet with Kim Jong-Un.

The summit took place on 12 June 2018 in Singapore. It concluded by issuing a joint statement that called for new relations, a commitment by President Trump to providing security guarantees for North Korea, North Korea 'reaffirming' a commitment to complete denuclearisation of the Korean Peninsula (through mutual confidence building); recovery of soldiers' remains from the Korean War, and a call for follow-up negotiations. ${ }^{56}$ Many found the document underwhelming, declaring that Kim had 'won' the summit as it did not commit Pyongyang to Complete Verifiable and Irreversible Dismantlement (CVID), and there were no concrete technical details for implementing the agreements. Some of these criticisms are misplaced. For a start, simply mentioning CVID in a joint document does not make it happen, and given the history between the DPRK and US, perceived betrayal even by the DPRK's erstwhile allies, and North Korea's understandable concern that disarming could leave them vulnerable to future US regime change efforts (as the example of Libya attests), an agreement to rapidly disarm was never likely. Instead a long-term, painstaking and incremental process was always the more likely course of action, with tit-for-tat confidence building efforts proving central to any diplomatic process. Critics also missed the fact that summits are not a place where states 'win' or 'lose' (a summit is not a conflict). Nor are they a venue where leaders sit down to hammer out the minutiae of technical policy issues or the day-to-day steps that will be taken to get to the end point (which are probably not known to either side yet). Rather such summits exist for dialogue at a high level to establish a political understanding for a process to begin.

The tenor of relations have oscillated. For example Trump called off Secretary Pompeo's August 2018 trip to Pyongyang, and then cut short a summit in Hanoi between Trump and Kim in February 2019. This was followed by a brief meeting on 30 June 2019, when Trump became the first sitting U.S. president to stand on North Korean soil when he entered the Korean Demilitarized Zone and which culminated in a three-way meeting between Trump, Kim and ROK President Moon Jae-in (meetings between senior officials have also continued).$^{57}$ Both sides have shown some restraint that suggest a cycle of confidence-building measures could take hold. For example, the ROK and US decided in March 2019 to terminate their annual Key Resolve and Foal Eagle joint military drills and in the same month the IAEA announced that the DPRK had not operated its Yongbyon $5 \mathrm{MW}(\mathrm{e})$ reactor capable of producing weapons-grade plutonium since early December $2018 .{ }^{58}$ And while an escalatory phase could be imminent, given Kim announced on 1 January 2020 that he was ending his nation's self-imposed moratori- 
um on nuclear and international ballistic missile testing, no test has occurred as of 25 January 2020.

Ultimately, while efforts to denuclearise Korea could very well fail, the initial TrumpKim summit has shifted the paradigm for US-North Korean relations. At the least, it has allowed de-escalation to take place. At the most, it creates a basis to move towards denuclearisation and eventual Korean reunification. As the next section explains, unlike past attempts to alter the equation on the peninsula, there are a number of factors that suggest cautious optimism is warranted.

\section{The North Korea's Diplomatic Dance: This Time it's Different}

The first key difference lies in the personalities at the table. On the US side there is President Trump - a figure unlike any of his recent predecessors. On one hand, Trump's penchant to shift positions rapidly and contradict himself could prove to be a significant impediment to sustained progress. On the other, Trump is clearly not concerned by normal diplomatic procedures that prevented his predecessors from making bold moves to change the political dynamic with the North. As such, rather than forcing Pyongyang to change its behaviour prior to the beginning of high-level dialogue, Trump flipped the equation to say dialogue would precede substantive change. Furthermore, Pyongyang might view Trump as an aberration in US presidents, and thus as an outsider who can make moves other US presidents could not (or would not), and thus true change can only be cemented with Trump in office and needs to occur before the US reverts to type. On the North Korean side, personality changes have also taken place. STRATFOR reports that Kim has removed many of the DPRK's leaders that had close ties to China, re-establishing some independence of action. ${ }^{59} \mathrm{Kim}$ is also part of a third generation of North Korean leaders who, unlike the first generation, never fought the US in the Korean War or, like the second generation, rose to power during the Cold War and were indoctrinated with Communist ideology. The new generation were often educated in Western Europe, have an understanding of the modern world and thus may be more willing to entertain serious thoughts of denuclearisation in exchange for real economic benefits and reunification with the south. ${ }^{60}$

A second difference is the deterioration of US-Chinese relations. While Trump's first year in power was characterised by a charm offensive vis-à-vis China, the gloves came off in the latter stages of 2017. The administration's National Security Strategy (released December 2017) and National Defence Strategy (released January 2018) labelled China a revisionist power that "seeks to displace the United States in the Indo-Pacific region." ${ }^{61}$ The increasing US military budget, warming ties between the US and Taiwan (a state Beijing considers a 'renegade province'), trade tariffs levelled against China and, indeed, the recent diplomatic initiatives involving North Korea, must be viewed in this context; the US is looking for areas around China's periphery where it can place pressure on Beijing. Forging the North Korean crisis into a bilateral Pyongyang-Washington 
diplomatic format that excludes Beijing does precisely this and could free up the US to devote more resources and attention to containing China's rise. It is also far from certain that Pyongyang would like to see the US exit the region entirely if it leaves China the dominant actor in Northeast Asia, a fact China will be acutely aware of and that will shape its own efforts to facilitate or impede US-DPRK diplomacy.

The Trump administration is also likely influenced by strategic concerns that the changing balance of power in the region will reduce its influence to shape events in Northeast Asia in the future. For example, a 2015 report by the Royal Institute of International Affairs that looked out to 2030 made the case that as China's economic growth continues, the region will become harder to manage. Essentially, as the power distribution between states in the region changes it becomes more difficult for leaders to clearly assess their operational environment, raising tension and chances for miscalculation. Compounding this is the fact power will continue to diffuse away from the state to non-state actors (a broader ongoing trend across the international system) and at the same time power itself becomes more multidimensional. ${ }^{62}$ This will reduce the influence of state actors, complicating efforts to understand who are the decisive actors in any given situation and making it harder for leaders to send clear signals. As such, the region will become more unpredictable and difficult to govern as new actors, challenges and technologies proliferate, leading to greater chances of policy paralysis in the face of a complex and rapidly changing environment. ${ }^{63}$ As such, 'solving' North Korea sooner rather than later becomes more important - the future could be less favourable to such an outcome and more dependent upon Beijing, which may seek to have the matter resolved in its favour.

The third difference taps into the history of Korea as a buffer state, and broader trends that are aligning the interests of the DPRK and ROK. The North's predicament is not dissimilar to that of the South: both states occupy a divided peninsula that is easily exploitable as a buffer and are at the mercy of external powers. Neither is in an ideal situation. At the same time, regional developments are weakening their separate positions and an increasingly assertive China is emerging. As noted, the North has reasons to view China with suspicion and an unreliable partner. Meanwhile, Seoul agreed to purchase US Ballistic Missile Defence (BMD) systems to defend itself against missile attack from the North in July 2016. China, viewing this as a threat to its own nuclear deterrent (and an adjunct of Washington's expanding array of global BMD systems), launched a campaign of economic retaliation against the South that lasted until 31 October $2017 .{ }^{64}$ Were the US to attack the North it would have devastating consequences for both the North and South, potentially unleashing a nuclear war (not to mention the North's artillery on Seoul) causing a long-term humanitarian disaster.

Therefore, both states are dependent on external powers that makes them vulnerable to decisions in foreign capitals and changing conceptions of national interest. On this score, Trump's repeated questioning of US defence commitments cannot be reassuring to Seoul, ${ }^{65}$ and as separate states the DPRK and ROK are weaker than they are together. 
Working to de-escalate tensions between them - and establish a basis for eventual reunification - will not allow the Koreas to free themselves from their geographic predicament, but it will increase their combined influence and give them more power to balance against external forces. This is the structural backdrop to their efforts to deescalate tensions, which have been ongoing since April 2018. It is a logical reaction to their joint (and worsening) predicament.

A point worth noting is the authoritarian nature of the North Korean regime and the incompatibility between it and South Korea, a liberal democracy. In short, authoritarian states are taken to prioritise regime survival above all else, have less respect for the rights of their own citizens (who they may actively repress), and can have hostile relations with democracies. ${ }^{66}$ All these weigh against rapprochement on the peninsula. While this is undoubtedly a complicating factor, history suggests it does not determine the future - for example, East Germany is now reunified with West Germany despite the fact virtually no one would have predicted it only a few years prior to reunification.

A final point worth considering here is that North Korea's return to the diplomatic table suggests it is more confident in its position. After all, it now has a fairly reliable nuclear weapons capability; even if diplomacy fails, it can fall back on this as its existential deterrent. At the same time, the programme's existence also constitutes the key bargaining chip that sustains dialogue with external actors, and if negotiations truly progress to a point where the regime feels it can trust external security guarantees, the nuclear program will be the chip that has got Pyongyang to that position.

\section{New Zealand's Options}

So what are New Zealand's options? The easy one is to stick to the status quo. This involves issuing statements in support of the diplomatic process and calling for restraint on all sides. To show some ambition, a maximalist approach would be to embrace 'strategic liberalism. ${ }^{67}$ This is consistent with the general foreign policy orientation pursued by Labour-led governments, who have sought to project liberal ideals into the international system. ${ }^{68}$ It reflects an understanding that globalisation facilitates cooperative norms and practices, and increases the incentives for cooperation to deal with thorny international problems that, through an increasingly interconnected international system, can reverberate far beyond their immediate region to affect even geographically remote states such as New Zealand. Threats can only be addressed through a view of security that requires states to work together. As a paradigm, strategic liberalism provides a wellspring for visionary objectives that contribute to the common security of the Asia-Pacific region and could help transcend regional security dilemmas (a security dilemma is a situation whereby a defensive state tries to improve its position relative to states that it perceives to be expansionist by increasing its military strength or establishing an alliance. This leads other states to respond in a similar fashion. This has the effect of heightening tension and increasing the chances of conflict even when 
no state desires it and when each only has defensive intentions. This is opposed to a situation where one state is offensive and where responding (balancing) by enhancing one's military capabilities is a rational response. Today, virtually every state is defensive, not offensively motivated for conquest. ${ }^{69}$

Strategic liberalism dovetails with comments made by New Zealand Minister of Foreign Affairs and Trade, Winston Peters, in June 2018 at the Otago Foreign Policy School. There he stated that part of New Zealand's influence internationally stems from its ability to act as an "honest broker," and that "Small thinking leads to small outcomes... It is not a time for intellectual timidity. It is a time for original thinking as we develop foreign policy prescriptions from adaptation rather than deliberate creation. Creative syntheses and challenging old verities is needed more than ever so be bold and take risks in your work. If you do you will find in this government a receptive ear to your ideas." 70 Peters may, in part, have had the DPRK in mind when he made these comments as in November 2007 he had made a rare trip for a foreign official when he visited Pyongyang to meet senior officials to discuss economic development and encourage the DPRK to meet its denuclearisation commitments under the Six Party Talks. ${ }^{71}$

\section{Strategic Liberalism - Core Principles and Assumptions}

- Anti-determinism; strategic futures are indeterminate

- Global interest; common interest; human interest

- Polylateralism; emphasise permanent partnerships

- Non-exclusionary; open and transparent activities

- Avant-garde; encouragement and utilisation of new thinking

- Best Practise; dissimulation of expertise and knowledge

- System-transcendent; approaches that seek to overcome security dilemmas

- Maximalism; strive for ambitious goals that maximise common interests

The two words that comprise Strategic Liberalism as a paradigm - 'strategic' and 'liberalism' - are not oxymoronic. Its prescriptions are strategic in that their pursuit is designed to improve the security position of the states involved in the endeavour, thus recognising their national interests, and liberal in that it requires and strengthens co- 
operation amongst them. It also holds that strategic futures are inherently indeterminate and that we need not repeat the tragic mistakes of the past. This approach also suggests New Zealand should emphasise 'open polylateralism': a commitment to permanent partnerships in international affairs and open multilateral architectures that do not exclude other states. This consciously runs counter to the foreign policy theory and approach known as realism, which hold that states only have interests, not permanent friends or allies. This is not an academic point: closed multilateral and security architectures generate feelings of insecurity amongst others, creating pressures to form countervailing alliances. This brings us back to the system-transcendent goals of strategic liberalism which, initially, could be directed towards overcoming security dilemmas in the Asia-Pacific region.

As it relates to North Korea, a maximalist objective through this framework would be for New Zealand to try play an instrumental role in supporting continued diplomatic efforts between the US and North Korea. As a first step, New Zealand could put itself forward as a location for an upcoming US-North Korean summit to promote cooperation and confidence building between them. In this, New Zealand can utilise its remote geographic position as neutral ground, as well as championing its historic role as a fair-minded honest broker, as Peters noted in Otago, and presumably contributed to the DPRK's willingness to meet with Peters in 2007. Additionally, North Korean citizens apparently have more positive feelings about New Zealand than they do other western nations owing to Wellington's anti-nuclear policy, hydropower expertise, and different foreign policy compared to that of the US and Australia. ${ }^{72}$

New Zealand could construct an explicit reassurance programme to promote between the US and North Korea. This would involve incremental step-by-step efforts in the military and non-military realms, centred on reciprocal restraint, in an effort to build trust and create a cycle of cooperation. Here, Wellington could draw upon the literature on 'reassurance' whereby initial signals act as feelers and require a corresponding reaction to induce further steps. ${ }^{73}$ The most significant signals involve a state opting to unilaterally decrease its forces and engage in joint arms control efforts to modify military postures and capabilities in a way that decreases the ability of states to challenge the status quo. ${ }^{74}$ Ultimately, reciprocal concessions must reach a point that makes it clear that neither state is considering attack or aggression.

Relatedly, New Zealand could champion an interesting proposal outlined by the military and legal scholar, Professor Philip Bobbitt. Bobbit has published a series of essays where he proposed China extend its nuclear umbrella over North Korea so that Pyongyang had less incentives to pursue a nuclear weapons program and China is reassured that it's role is cemented in the diplomatic process. ${ }^{75}$ In turn, the US nuclear umbrella over its allies would remain. While this risks locking in 'spheres of influence', and the DPRK could prove resistant owing to its view that foreign states are unreliable, Bobbitt concludes that all the other options - (1) sanctions and threats, (2) a military strike by 
the US to 'solve' the problem and (3) containment of Pyongyang that inevitably leads Japan and the ROK to go nuclear - do not establish a basis for long-term success. After rejecting the alternatives, Bobbitt makes his case for a nuclear guarantee to be provided to Pyongyang by China. This, itself, would not solve the situation, rather it would be the foundation for an additional series of initiatives to be pursued, one of which would be a US-organised conference to include the Koreas, the US, China, Japan and Russia. The objective from the outset would be to end the Korean War and codify final borders.

Clearly, a diplomatic breakthrough that leads to a denuclearised Korea would conform with Wellington's longstanding, and recently re-energised, dedication to nuclear nonproliferation. A fully nuclearized, yet still isolated, North Korea will ensure conflict remains a possibility and regional tensions high. Yet, there are also wider regional implications to any resolution. As such, the best outcome would be an agreement that includes all regional players, and not one where Seoul and Washington resolve the crisis without Beijing sitting at the table. This could simply lead to the solution to one long-standing crisis but the emergence of another, as the US-China strategic competition moves to centre stage with Beijing chaffing at being humiliated and potentially strategically disadvantaged by being excluded from a diplomatic resolution on its doorstep. This is the hidden danger of success. At a minimum, to the extent New Zealand has a voice and is willing to use it, it should encourage negotiations that include all the major states in Northeast Asia.

\section{Conclusion}

To explain that Pyongyang's efforts to develop a nuclear deterrent to secure its survival is not to be an apologist for a brutal regime. Rather, it is to understand that North Korea's nuclear quest as being a response to a hostile and unforgiving environment, unreliable 'allies', and to a history dictated by its geography that has made it a buffer state vulnerable to the predations of external powers. While North Korea cannot be comforted by the changes it sees taking place all around it, at the same time, a number of factors appear to be driving the interests of the DPRK, the ROK, and the US closer together. In this instance, uncertainty, threat and Trump's ability to break norms has created a foundation for transforming the diplomatic status quo. Given the record of diplomacy, there is no certainty that current efforts will succeed but seeing them do so is in New Zealand's national interests: a shock in Northeast Asia could throw the global economy into a tailspin; or a direct military confrontation between regional states - or with the US - could force New Zealand to make decisions in favour of one party that hurts its relations with others; and New Zealand's military could be embroiled in a coalition or UN response to conflict. As such, Wellington should work to support diplomatic efforts to the extent it can while encouraging efforts that ensure all the major regional players have a say in the eventual outcome. An inclusive peace on the peninsula could be sustainable and contribute towards an emerging world order founded on great power 
cooperation between the US and China; a solution where either feels their interests are not taken into account will be a peace in name only, and portend the emergence of more dangerous and conflictual world order.

Admittedly, it is not hard to think of critiques to the proposal outlined above, and it does come with risks. The first is reputational. In short, the reputation New Zealand currently has for being a neutral and relatively independent foreign policy player has benefits; a well-meaning diplomatic effort - but one that leaves New Zealand looking incompetent and misguided could harm this brand. It would therefore be remiss of New Zealand to put itself forward if it did not have relevant expertise in its foreign policy core, something it should consider actively developing. One could also make the case that other regional issues, like the South China Seas, are deserving of broker engagement. Ultimately, though, New Zealand has to weigh up the fact that it has limited means - enacting a much broader pro-active foreign policy posture in the region would require a redirection of foreign policy resources (and thus influence) from elsewhere. Furthermore, while word constraints do not allow space here to provide a deep discussion, the territorial disputes in the South China Seas involve many actors as well as an emerging superpower (China) that has, it would appear, essentially secured its position in the Seas. Any agreement to resolve the disputes there will be on China's terms. In contrast, as this article notes, a range of factors seem to be improving the long-term prospects on the Korean peninsula, while New Zealand already has a potential angle into the North Korean standoff owing to Winston Peter's 2007 trip.

Ultimately, it is essential to recognise that rapprochement is often a long-term and iterative process ${ }^{76}$ Those claiming the Trump administration's efforts are 'failing' are missing the point that it was never likely that Pyongyang would rapidly give up its nuclear arsenal and normalise its relations with the outside world without strong and convincing evidence that the regime would not be threatened if it did so. What would assuage Pyongyang's concerns? Likely, it would be a peace treaty with the US, discussion over the disposition of forces on the peninsula and an agreement on reunification with South Korea (or, barring that, some other kind of agreement with the South). While this is a tall order, and it could take a decades-long effort to get there, it is a goal New Zealand should do its utmost to support. 
1 Congressional Research Service, North Korea: U.S. Relations, Nuclear Diplomacy, and Internal Situation, 27 July 2018. Available at https://fas.org/sgp/crs/nuke/R41259.pdf

2 See comments on North Korea in: New Zealand Government, Strategic Defence Policy Statement 2018, 6 July 2018. Available at: http://www.nzdf.mil.nz/downloads/pdf/public-docs/2018/strategic-defence-policy-statement-2018.pdf; New Zealand Ministry of Foreign Affairs and Trade, Strategic Intentions 2018-2022, p.2. Available at: https:/www.mfat.govt.nz/assets/MFAT-Corporate-publications/ MFAT-Strategic-Intentions-2018-2022.pdf

3 This draws from ideas in Gregory D. Foster, 'Transforming US National Security: A Call for Strategic Idealism’, Defense \& Security Analysis, 26:2 (2002), pp.129-42.

4 Michael Richardson, "Planned New Zealand Defence Cuts Worry Troubled Region," International Herald Tribune News, 17 February 2001. Available at: http://www.iht.com/articles/2001/02/17/ zeal.2.t.php

5 New Zealand Government, Strategic Defence Policy Statement 2018.

6 Ibid, 21

7 Ibid, 27

8 New Zealand Ministry of Foreign Affairs and Trade, Strategic Intentions 2018-2022.

9 For a consideration of the costs of conflict on the Korean peninsula, see John Fetter, "North Korea:

The Costs of War, Calculated." Available at: https://ips-dc.org/north-korea-costs-war-calculated/

10 Reuben Steff and Francesca Dodd-Parr, "Examining the Immanent Dilemma of Small States in the Asia-Pacific: The Strategic Triangle between New Zealand, the US and China," The Pacific Review (January 2018), pp. 1-23.

11 US ambassasor to New Zealand, Scott Brown, has made this case. See "North Korea poses "direct danger' to NZ, US ambassador Scott Brown warns," New Zealand Herald, 2 October 2017. Available at: https://www.nzherald.co.nz/nz/news/article.cfm?c id=1\&objectid=11928626

12 "North Korea threatens Australia with disaster if it continues to support US stance on Pyongyang," 15 October 2017, ABC/Reuters. Available at: http://www.abc.net.au/news/2017-10-15/north-korea-warns-australia-face-disaster-continues-support-us/9051156; "N. Korea berates Australia for hostile moves, warns of disaster," The Korea Times, 14 October 2017. Available at: http://www.koreatimes. co.kr/www/nation/2018/06/103_237658.html

13 Andrew Duver, "Dairy: June Quarter 2019," 4 November 2019. Available at: https://www.agriculture.gov.au/abares/research-topics/agricultural-commodities/jun-2019/dairy; "Fonterra keeping eye on Ukraine," Radio New Zealand. Available at: https://www.rnz.co.nz/news/rural/255439/fonterra-keepingeye-on-ukraine

14 "New Zealand-Russia FTA: Another BRIIC in the wall," 16 November 2010, New Zealand Institute of Economic Research. Available at: https://nzier.org.nz/publication/new-zealand-russia-fta-anotherbriic-in-the-wall-nzier-insight-21

15 Tanisha M. Fazal, "State Death in the International System," International Organization, 58(2)

(Spring 2004), pp. 311-344.

16 Slight alterations have been made to the map by this article's author.

17 Bruce Cumings, The Korean War: A History (New York: Modern Library, 2013).

18 Zenel Garcia, China's Military Modernization, Japan's Normalization and the South China Sea Territorial Disputes (Palgrave Pivot, 2019); also see Asian Military Review. Available at: https://asianmilitaryreview.com/category/regions/east-asia/south-korea/

19 Jonathan D. Pollack, No Exit: North Korea, Nuclear Weapons and International Security (Adelphi Series) (London: IISS, 2011), p. 44.

20 Ibid, p. 50.

21 Pollack, No Exit, p. 57.

22 Cheng Xiaohe, "The Evolution of Sino-North Korean Relations in the 1960s," Asian Perspective, 34(2) (2010), pp. 173-99, 190-92.

23 Victor Cha and David Kang, Nuclear North Korea (New York: Columbia University Press, 2003), p. 149.

24 Cited in Van Jackson, Rival Reputations: Coercion and Credibility in U.S.-North Korea Relations (Cambridge: Cambridge University Press, 2016), p. 151.

25 Jeffrey R. Smith, "Perry Sharply Warns North Korea," Washington Post, 31 March 1994. 
26 US Department of State, "Agreed Framework." Available at: http://2001-2009.state.gov/t/ac/rls/ or/2004/31009.htm. For a fuller account of Carter's intervention see Marion V. Creekmore, A Moment of Crisis: Jimmy Carter, the Power of a Peacemaker and North Korea's Nuclear Ambitions (New York: Public Affairs, 2006).

27 Sheryl Wudunn, "North Korea Fires Missile Over Japanese Territory," New York Times, 1 September 1998; “An Intelligence Fiasco,” The Chosunilbo, 6 September 1998. Available at: http://english.chosun. com/site/data/html_dir/1998/09/06/1998090661255.html

28 Nicholas Khoo and Reuben Steff, Security at a Price : The International Politics of U.S. Ballistic Missile Defense (Rowman \& Littlefield, 2017).

29 “Text of President Bush's 2002 State of the Union Address," The Washington Post, 29 January 2002. Available at: http://www.washingtonpost.com/wp-srv/onpolitics/transcripts/sou012902.htm?noredirect $=$ on. For more on pre-emption see Robert Jervis, "Understanding the Bush Doctrine," Political Science Quarterly, 118(3) (2003), pp. 365-388.

30 Jonathan D. Pollack, "The United States, North Korea, and the End of the Agreed Framework," Naval War College Review, 56(3) (Summer 2003), p. 11.

31 Pollack, No Exit, 145.

32 Ibid, 149.

33 United Nations Security Council Resolution 1695, 15 July 2006. Available at: http://www.un.org/ press/en/2006/sc8778.doc.htm

34 United Nations Security Council Resolution 1718, 14 October 2006. Available at: https://www. un.org/press/en/2006/sc8853.doc.htm

35 Hillary Clinton, "Remarks with Croatian Foreign Minister Gordan Jandrokovic after Their Meeting," US Department of State, 10 December 2009, Washington D.C. Available at: https://2009-2017. state.gov/secretary/20092013clinton/rm/2009a/12/133416.htm

36 "N Korea defends nuclear test citing fate of Saddam, Gaddafi," Asia Times. Available at:

https://www.asiatimes.com/2016/01/article/n-korea-defends-nuclear-test-citing-fate-of-saddam-gaddafi/

37 "North Korean Missile Launches \& Nuclear Tests: 1984-Present," Missilethreat.com, 29 November 2017. Available at: https://missilethreat.csis.org/north-korea-missile-launches-1984-present/

38 Cary Huang, "President Xi Jinping issues call for regional stability," South China Morning Post, 7 April 2013. Available at: https://www.scmp.com/news/china/article/1209104/president-xi-jinping-issues-call-regional-stability

39 Jane Perlez, "China Ban on Items for Nuclear Use to North Korea May Stall Arms Bid," New York Times, 29 September, 2013.

40 "Leaked U.S. Cable Indicates North Korean leader Kim Jong-Il Does Not Trust

China," Taipei Times, 6 September 2011. Available at: http://taipeitimes.com/news/world/ archives/2011/09/06/2003512607

41 “Wikileaks cables: China 'frustrated' by North Korea," BBC, 30 November 2010. Available at: https://www.bbc.com/news/world-us-canada-11871641

42 Barry Rubin explained that labelling a state a 'rogue' was akin to giving them "a certificate of political insanity." Barry Rubin, "US Foreign Policy and Rogue States," Middle East Review of International Studies, 3(3) (September 1999), pp. 49-57. In 2016 as a presidential candidate Donald J. Trump stated "If you look at North Korea, this guy, I mean, he's like a maniac..." Quoted in Somini Sengupta and Jane Perlez, "U.N. Stiffens Sanctions on North Korea, Trying to Slow its Nuclear March," New York Times, 30 November, 2016; Nikki Haley, US Ambassador to the UN, stated in reference to Kim Jung-Un, "We are not dealing with a rational person." Liu Chen, "Seeking To Ease Tensions, China Proposes Trade-Off," South China Morning Post, 9 March, 2017. It appears that since Trump and Kim met in June 2018, no senior US officials have suggested Kim is irrational.

43 Campbell Craig claims that this would bring the unipolar system into a state of 'disequilibrium'. See Campbell Craig, "American Power Preponderance and the Nuclear Revolution," Review of International Studies, 35(1) (January, 2009), pp. 27-44.

44 The American strategist Thomas Schelling is often attributed with formalising the idea that acting as though one were irrational - including by increasing the risk of nuclear conflict - can be a rational course of action for states seeking to gain leverage. See Thomas Schelling, The Strategy of Conflict (Cambridge: Harvard University Press, 1960); Arms and Influence (New Haven: Yale University Press, 1966). 
45 As former Secretary of Defense William Perry recently stated, "this is not a crazy regime; it is an evil regime, it is a reckless regime, but it's not crazy. They are oriented almost entirely around regime survival." Barbara Demick, "Former Defense Secretary On Why We Didn't Go To War With North Korea," Los Angeles Times, 14 April 2017.

46 Khoo and Steff, Security at a Price, p. 97.

47 Scott Sagan writes that rational theory is a poor basis for predicting state behaviour since "nuclear weapons are not controlled by states, they are not controlled by statesmen. They are managed by imperfect, normal human beings inside imperfect, normal organizations." Amitai Etzioni, "Rational Actors: Neither Mad nor M.A.D.: The Meanings of Rationality, Rogue States and Terrorists," Defense \& Security Analysis, 26(4), pp. 43-38. Quote cited on p. 435.

48 "North Korean Missile Launches \& Nuclear Tests," Missilethreat.com.

49 Gerald F. Seib, Jay Solomon and Carol E. Lee, "Barack Obama Warns Donald Trump on North Korea Threat," Wall Street Journal, 22 November 2016. Available at: https://www.wsj.com/articles/ trump-faces-north-korean-challenge-1479855286

50 Tillerson was categorical: "Let me be clear: the policy of strategic patience has ended. We are exploring a new range of security and diplomatic measures." Justin McCurry, "Military Action against North Korea 'An Option,' Warns Rex Tillerson," Guardian, 17 March, 2017.

51 Justin McCurry, "Mike Pence Warns North Korea: 'Era of Strategic Patience is Over"”, Guardian, 16 April, 2017; Charlie Campbell, "President Trump Says China Could 'Easily' Rein in North Korea," Time, 9 November 2017. Available at: http://time.com/5016617/donald-trump-china-north-korea-2/

52 Quoted in Julian Borger, "Donald Trump: I'd Be Honored to Meet Kim Jong-Un Under 'Right Circumstances", Guardian, 1 May 2017.

53 Thomas Christensen, "The Contemporary Security Dilemma: Deterring A Taiwan Conflict," Washington Quarterly, 25(4) (2002), pp 5-21, p. 10.

54 Andrew Buncombe, "Donald Trump's explosive UN speech: Read it in full," The Independent, 19 September 2017. Available at: https://www.independent.co.uk/news/world/americas/us-politics/trumpun-speech-read-in-full-transcript-north-korea-general-assembly-a 7956041.html

55 Christine Kim and Soyoung Kim, "North Korea's Kim says will make 'deranged' Trump pay dearly for U.N. speech," 22 September 2017. Available at: https://www.reuters.com/article/us-northkorea-missiles-statement/north-koreas-kim-says-will-make-deranged-trump-pay-dearly-for-u-n-speech-idUSKCN1BW32D?il=0

56 "Joint Statement of President Donald J. Trump of the United States of America and Chairman Kim Jong Un of the Democratic People's Republic of Korea at the Singapore Summit," White House, 12 June 2018. Available at: https://www.whitehouse.gov/briefings-statements/joint-statement-president-donald-j-trump-united-states-america-chairman-kim-jong-un-democratic-peoples-republic-korea-singapore-summit/

57 "Chronology of U.S.-North Korean Nuclear and Missile Diplomacy," Arms Control Association, July 2019. Available at: https://www.armscontrol.org/factsheets/dprkchron

58 Ibid.

59 Rodger Baker, "Here's What's Actually Different About the Latest North Korea Talks," STRATFOR, 5 April 2018. Available at:

https://worldview.stratfor.com/article/heres-whats-actually-different-about-latest-north-korea-talks

60 Ibid.

61 National Defense Strategy of the United States of America, Department of Defense, January 2018. Available at: https://dod.defense.gov/Portals/1/Documents/pubs/2018-National-Defense-Strategy-Summary.pdf; National Security Strategy of the United States of America, White House, December 2017. Available at: https:/www.whitehouse.gov/wp-content/uploads/2017/12/NSS-Final-12-18-2017-0905.pdf 62 Anne-Marie, Slaughter, The Chessboard and the Web: Strategies of Connection in a Networked World (London, England: Yale University Press, 2017).

63 "The Asia-Pacific Power Balance: Beyond the US-China Narrative," Chatham House (Royal Institute of International Affairs), 27 September 2015. Available at: https://www.chathamhouse.org/publication/asia-pacific-power-balance-beyond-us-china-narrative

64 Ethan Meick and Nargiza Salidjanova, "China's Response to U.S.-South Korean Missile Defense System Deployment and its Implications," U.S.-China Economic and Security Review Commission, 26 July 2017. Available at: https://www.uscc.gov/sites/default/files/Research/Report_China\%27s\%20Re- 
sponse \%20to\%20THAAD\%20Deployment\%20and\%20its\%20Implications.pdf; Christine Kim and Ben Blanchard, "China, South Korea agree to mend ties after THAAD standoff," 31 October 2017, https:// www.reuters.com/article/us-northkorea-missiles/china-south-korea-agree-to-mend-ties-after-thaad-standoff-idUSKBN1D003G

65 Jonathan Swan, "Scoop: Trump urges staff to portray him as "crazy guy", Axios, 2 October 2017, https://www.axios.com/scoop-trump-urges-staff-to-portray-him-as-crazy-guy-1513305888-c1 cbdb896370-4e13-98ed-28c414e62a35.html

66 Michael E. Brown, Sean M. Lynn-Jones, and Steven E. Miller. Debating the Democratic Peace (Cambridge, Mass.: MIT Press, 1996).

67 Reuben Steff, "Strategic Liberalism and Kiwi Maximalism," New Zealand International Review, 41(2) (2016) pp. 14-17.

68 In the New Zealand context, David McCraw has written extensively on this. For example, see David McCraw, "Idealism and Realism in the Foreign Policy of the Fourth Labour Government," Political Science, 53(2) (2001) pp. 21-37.

69 Shiping Tang, “The Security Dilemma: A Conceptual Analysis," Security Studies, 18(3) (2009) pp. 597-623.

70 Rt Hon Winston Peters, "Next Steps,” 29 June 2018. Available at: https://www.beehive.govt.nz/ speech/next-steps

71 "Peters reports back to US on N Korea," New Zealand Herald, 20 November 2007. Available at: https://www.nzherald.co.nz/nz/news/article.cfm?c_id=1\&objectid=10477218

72 Paul Bellamy has written extensively on New Zealand's relations with North Korea. See Paul Bellamy, “A Reluctant Friend: New Zealand's Relationship with North Korea: 1973-1989," New Zealand Journal of Asian Studies, 14(1) (June 2012), pp. 30-48; Paul Bellamy, "Seeking constructive dialogue with North Korea," New Zealand International Review, 43(1) (January/February 2018, pp. 13-15); Paul Bellamy, “"An Awfully Long Time': Establishing New Zealand-North Korea Diplomatic Relations,” New Zealand Journal of Asian Studies, 15(2) (December 2013), pp. 24-44.

73 Of critical importance is assuming that cooperation between democracies and autocracies is possible. See Charles A. Kupchan, How Enemies Become Friends: The Sources of Stable Peace, (Princeton University Press: Princeton, 2010) p. 408.

74 Evan Braden Montgomery, "Breaking Out of the Security Dilemma Realism, Reassurance, and the Problem of Uncertainty," International Security, 31(2) (Fall 2006), pp. 151-85, p. 152.

75 Bobbitt's essays can be found on his blog. See Philip Bobbitt, "What to Do About North Korea," Lawfare. Available at: https://www.lawfareblog.com/what-do-about-north-korea

76 Kupchan, How Enemies Become Friends. 